BALDUINIA, n. 32, p. 01-06, XV-X-2011

\title{
A NEW SPECIES OF LESSINGIANTHUS (ASTERACEAE: VERNONIEAE), FROM RIO GRANDE DO SUL STATE, BRAZIL ${ }^{1}$
}

\author{
LEONARDO PAZ DEBLE² RAFAEL PLÁ MATIELO LEMOS ${ }^{3}$
}

\begin{abstract}
Lessingianthus alegretensis (Asteraceae: Vernonieae) is described and illustrated from sandy grasslands in southwest of Rio Grande do Sul State, Brazil. Comments about geographic distribution, conservation and affinities are provided.

Key words: Asteraceae, Compositae, Conservation, Lessingianthus, Pampa Biome, Taxonomy.
\end{abstract}

\section{RESUMO}

[Uma nova espécie de Lessingianthus (Asteraceae: Vernonieae) do Estado do Rio Grande do Sul, Brasil].

Lessingianthus alegretensis (Asteraceae: Vernonieae) é descrita e ilustrada para os campos arenosos do sudoeste do estado de Rio Grande do Sul, Brasil. São fornecidos dados referentes à distribuição geográfica, afinidades e conservação.

Palavras-chave: Asteraceae, Bioma Pampa, Compositae, Conservação, Lessingianthus, Taxonomia.

\section{INTRODUCTION}

Lessingianthus Robinson (1988a: 929) comprises more than 120 species, widely distributed in South America, with important centers of diversity in southern and central Brazil, mainly on grasslands and stony grasslands (Bremer, 1994; Dematteis \& Angulo, 2010). The genus can be characterized by a combination of following features: perennial herbs or shrubs, cymose inflorescence, medium to large-sized capitula, eglandular anthers appendices, lack of a basal style node, quadrate raphids on cypsela wall, and basic chromosome number $\mathrm{x}=16$, whereas the majority of South America Vernonieae Cassini (1819: 203) genera have $\mathrm{x}=17$, and the closely related genus Chrysolaena Robinson (1988b: 956) $\mathrm{x}=10$, and pollen grains, tricolporate, echinolophate, with

1 Recebido em 15-8-2011 e aceito para publicação em 12-9-2011.

2 Curso de Ciências Biológicas, Universidade da Região da Campanha - URCAMP; Bagé, Rio Grande do Sul, Brazil. e-mail: deble.biol@gmail.com.

3 Curso de Ciências Biológicas, Universidade da Região da Campanha - URCAMP; Fundação Universidade Federal do Pampa - UNIPAMPA; Bagé, Rio Grande do Sul, Brazil. e-mail: rafael.matielo@unipampa.edu.br. a discontinuous tectum, very long germinal furrows, that converge at the poles with lacunae disposed in a regular pattern, and lacking a polar lacunae (type B) (Keeley \& Jones, 1979; Dematteis \& Angulo, 2010).

Since the description of Lessingianthus, few additions were made to the genus, with descriptions of new species (Diaz-Piedrahita \& Obando, 2002; Deble et al., 2005; Dematteis, 2006; Borges \& Dematteis, 2008) and the transfer of the Lessingianthus subgenus Oligocephalus Robinson (1988a: 949) to Chrysolaena (Dematteis, 2007). Most recently, thirteen new combinations and two new species were proposed to Brazil and neighbours areas (Dematteis \& Angulo, 2010).

The number of species is uncertain to Rio Grande do Sul State; Matzenbacher \& Mafioleti (1994b) treated 12 species under Vernonia Schreber (1791: 541). Then, with additions of new species and citations above 15 taxa occur in this State (Matielo-Lemos, 2011).

Along the survey of the Asteraceae Family from Rio Grande do Sul State (Brazil) made by first author and the anatomical studies in the complex of Lessingianthus macrocephalus (Lessing, 1929: 298; Robinson, 1988a: 944), 
realized by the second author, it was evidenced a new species, which appears endemic on sandy grasslands in southwest Rio Grande do Sul State.

\section{RESULTS}

Lessingianthus alegretensis Deble \& R. Matielo, sp. nov. (Figure 1, 2)

A Lessingiantho macrocephalo similis sed habitu minoribus $(25-70 \mathrm{~cm} v \mathrm{~s} .60-120 \mathrm{~cm}$ altus), capitulis magnis (20-24 mm altis vs. 16-20 mm altis), phyllariis pluriseriatis (68-seriatis vs. 5-6-seriatis), indumentum adpressum (vs. non adpressum), nitudoincanum (vs. grisaceum ad ochregrisaceum), et pilis cum cellulis terminalibus paries angustatis (vs. non angustatis), productis bene differt.

Typus: BRAZIL. Rio Grande do Sul: Alegrete, Santo Antônio, sandy grasslands, shrubs $30-40 \mathrm{~cm}$ high, purplish flowers, 21 November 2006, L. P. Deble \& A. S. de Oliveira-Deble 8093 (holotypus SI! isotypus CTES!).

Erect shrubs, $25-70 \mathrm{~cm}$ high, with xylopodia. Stems 1-3, with few branches in the distal portion, and densely leafy in proximal portion, sparsely distally, and covered by shine white lanose indumentum, composed by adpressed trichomes, with 2-3 cells at the base, and a filiform terminal cell with narrowed wall, and $1.100-1.600 \mu \mathrm{m}$ long. Leaves spirally alternate, ascending, sessile or shortly petiolate (petiole up to $8 \mathrm{~mm}$ ), obovate to elliptic, $3.5-13 \times 2$ $4.5 \mathrm{~cm}$; leaf blades coriaceous, camptodromous, strongly discolorous, olive-green or brownishgreen, glabrous or pubescent above the veins adaxially and shine white, densely pubescent in abaxial surface, trichomes like those of stems. Bracts leafy, ovate to lanceolate, gradually smaller distally, 4-5.5 × 1.3-2.5 cm, at the apex acute, base truncate to amplexicaul. Capitula sessile or pedunculate, in a laxe corymb, of 6$35 \mathrm{~cm}$ long, and bearing 2-6 capitula. Involucre broadly campanulate, $20-24 \times 25-35 \mathrm{~mm}$. Phyllaries in 6-8-series, reddish-brown to darkbrow, frequently with a constriction in the distal third or near at the apex; outermost densely pubescent, median sparsely pubescent, with a tufted of trichomes in the distal third, and innermost glabrescent, or with few trichomes at the apex. Outer phyllaries ovate, 3.5-6 $\times 2.3-$ $3.2 \mathrm{~mm}$; median phyllaries lanceolate to ellipticlanceolate, 7-12 × 2.5-3.5 mm; inner phyllaries elliptic-lanceolate to linear-elliptic, 13-18 $\times$ 1.8-3 mm. Flowers 70-160; corolla purple, glabrous, $19-23 \mathrm{~mm}$ long, at the apex with five lobes; tube 11-15 mm long, lobes linear 5.5-8 $\times 0.6-0.9 \mathrm{~mm}$. Style purple to light pink, $18.5-$ $22 \mathrm{~mm}$ long; branches filiform, 3.5-6 mm long. Anthers 6.5-7.5 mm long, basally short caudate, apical appendage ovate ca. $0.5 \mathrm{~mm}$ long. Cypsela obconical, 4-5 mm long, ribbed, sericeous-pubescent; twin-trichomes 400-500 $\mu \mathrm{m}$ long; carpopodium $0.3 \mathrm{~mm}$. Pappus biseriate, yellowish, outer series composed by triangular scales, $1.5-3 \mathrm{~mm}$ long, inner series setaceous 10-12 mm long. Pollen grains spheroidal, echinolophate, 40-50 ì $\mathrm{m}$ in diameter, tricolporate, regularly areolate, spiculate.

Distribution and habitat:Lessingianthus alegretensis grows on sandy grasslands and adjacent stony grasslands in Alegrete, Rosário do Sul, São Francisco de Assis and Manoel Viana cities, in southwest of Rio Grande do Sul State (Figure 2). Material with flowers and fruits are gathered between October-March.

Etymology: This species is named after the place of type collection.

Material examined (Paratypi): BRAZIL. Rio Grande do Sul: Alegrete, arroio Lajeado, 26 January 1986, J. Mattos \& N. Mattos 29735 (HAS!); sandy grassland, $60 \mathrm{~cm}$, discolor leaves, lilac flowers, 14 January 2007, L. P. Deble \& A. S. Oliveira-Deble, 7105 (CTES!); road to Rosário do Sul, in sandy grassland and adjacent sandstone area, 7 March 2011, L. P. Deble, A. S. Oliveira-Deble \& R. Matielo, 12885 (CTES!). Manoel Viana, 7 December 1982, J. Mattos \& N. Mattos 23791 (HAS!). São Francisco de Assis, 9 December 1982, J. Mattos \& N. Mattos 


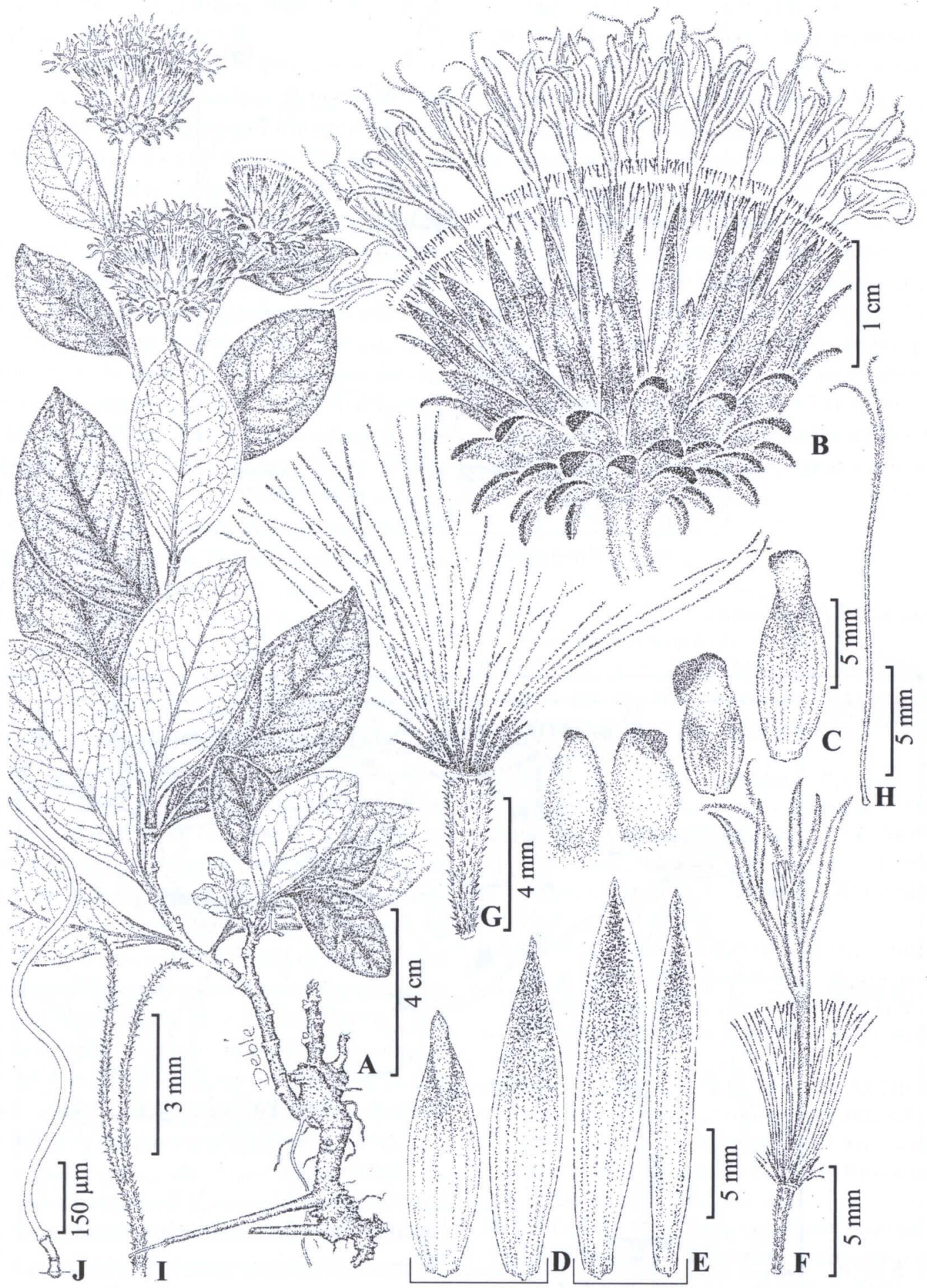

FIGURE 1 - Lessingianthus alegretensis. A. Habit. B. Capitulum. C. Outer phyllaries. D. Median phyllaries. E. Inner phyllaries. F. Flower. G. Cypsela and pappus. H. Style. I. Style apex. J. Trichome (leaf) (A-F, H-J Deble \& OliveiraDeble 8093, CTES!. G Deble et al. 12885, CTES!). 


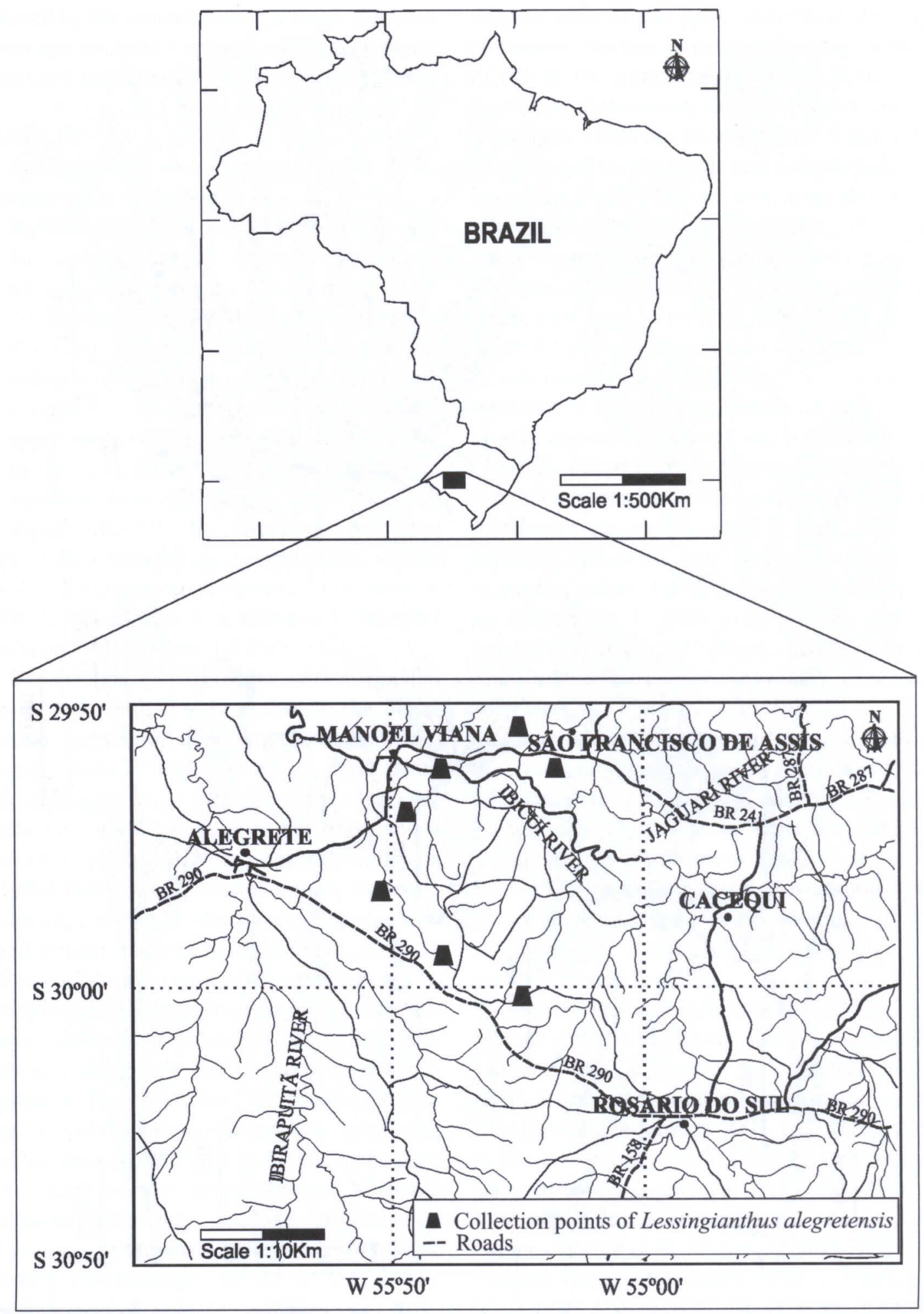

FIGURE 2 - Geographic distribution of Lessingianthus alegretensis. 
23663 (HAS!); 23 October 1986, J. Mattos \& N. Mattos 30100 (HAS!).

Conservation Status: Evidence of the occurrence of Lessingianthus alegretensis was found in the Municipalities of Alegrete, Manoel Viana, Rosário do Sul and São Francisco de Assis with extent of occurrence estimated in less than $20,000 \mathrm{~km}^{2}$, and area of occupancy estimated in less than $2,000 \mathrm{~km}^{2}$. In addition, anthropogenic pressures such as agriculture, silviculture, and urban expansion affect directly this area. Due to the observed threats, it is prudent to include $L$. alegretensis in the Vulnerable category of the IUCN Red List of endangered plant species according to the following criteria (IUCN 2010): VU B1, B2a, b (iii) $+\mathrm{C}$.

Relationships: Lessingianthus alegretensis by large-sized capitula, bigger coriaceous leaves and number of flowers per capitula is most closely related with both: Lessingianthus macrocephalus and L. magnificus Deble, Dematteis \& Marchiori (2005:1). It differs of the first-one species by smaller habit $(25-70 \mathrm{~cm}$ vs. $60-120 \mathrm{~cm})$, larger capitula (20-24 mm high vs. 16-20 mm high), multiseriate phyllaries (68 -series vs. 5-6-series), and principally by shiny white indumentum (vs. grayish to ochregrayish), strongly adpressed at stems and leaves (not adpressed), with trichomes having terminal cell with narrowed wall (vs. all cells of trichomes with equal thickness of wall). From Lessingianthus magnificus can be separated by its smaller habit ( $25-70 \mathrm{~cm}$ vs. $80-160 \mathrm{~cm})$, and its innermost phyllaries sparsely pubescent, at the apex acute (vs. densely pubescent, at the apex obtuse). Furthermore, Lessingianthus alegretensis display purplish flowers and occurs principally in sandy grasslands, while $L$. macrocephalus and L. magnificus show pale lilac flowers, and it are restrict in rocky places. The allopatric L. correntinus (Cabrera \& Cristóbal, 1978:129) Dematt. in Dematteis \& Angulo (2010: 236), which occurs in northeastern Argentina, is probably also related to the new species, but easily differs by narrowly elliptic leaves. L. constrictus (Matzenbacher \& Mafioleti 1994a: 19) Dematt. in Dematteis \& Angulo (2010: 236), which grows in bogs near to coastline of Rio Grande do Sul, might also be allied with $L$. alegretensis, both species display innermost phyllaries with acute apices, and median and inner phyllaries with an apically (or in the distal third) constriction. However, $L$. constrictus has fewer indumentum above stems and leaves, and capitula with 14-16 mm high (vs. 20-24 mm high). Not fully developed specimens of $L$. alegretensis resemble $L$. lorentzii Hieronymus (1897: 674) Robinson (1988a: 944), but this species easy differs by smaller solitary capitula (rarely geminate), and leafy outermost phyllaries.

\section{REFERENCES}

BAKER, J. G. (1873). Compositae I. Vernoniaceae. Flora Brasiliensis 6 (2): 1-179.

BORGES, R. A. X. \& DEMATTEIS, M. (2008). A new species of Lessingianthus (Asteraceae: Vernonieae) from Minas Gerais, Brazil. Brittonia 60 (4): 377-381.

BREMER, K. (1994). Asteraceae Cladistic and Classification: Timber Press, Portland: 1-752.

CABRERA, A. L. \& CRISTÓBAL, C. L. (1978). Una nueva especie del género Vernonia (Compositae) de Corrientes (Argentina). Hickenia 1: 129-131.

CASSINI, H. (1819). Suite du sixièmes mémoire sur la famille des Synanthérées, contenant les caractères des tribus. Journal de Physique, de Chimie, et d'Histoire Naturelle et des arts 88 : 189-204.

DEBLE, L. P., DEMATTEIS, M. \& MARCHIORI, J. N. C. (2005). Lessingianthus magnificus Deble, Dematteis \& Marchiori (Asteraceae) nova espécie do norte do Uruguai e Rio Grande do Sul (Brasil). Balduinia 5: 1-3.

DEMATTEIS, M. (2006). Two new species of Lessinngianthus (Vernonieae, Asteraceae) from the Brazilian highlands. Botanical Journal of Linnean Society 150: 487-493.

DEMATTEIS, M. (2007). Taxonomic notes on the genus Chrysolaena (Vernoniae, Astereae), 
including a new species endemic to Paraguay. Annales Botanici Fennici 44: 56-64.

DEMATTEIS, M. \& ANGULO, M. B. (2010). Additions to the genus Lessingianthus (Asteraceae, Vernonieae), from South America. Rodriguésia 61 (2): 233-241.

DIAZ-PIEDRAHITA, S. \& OBANDO, S. (2002). Novedades en Vernonieae (Asteraceae) de Colombia. Revista de La Academia Colombiana de Ciências Exactas 61: 347-351.

HIERONYMUS, G. (1897). Erster beitrag zur kenntnis der Siphonogamenflora der Argentina und der angrenzenden länder, besonders von Uruguay, Paraguay, Brasilien und Bolivien. Botanische Jahrbücher für Systematik 22(4-5): 672-798.

IUCN (2010) Guidelines for Using the IUCN Red List Categories and Criteria. Version 8.1. Prepared by the Standards and Petitions SubCommittee in March 2010. Available from: http:/ /intranet.iucn.org/webfiles/doc/SSC/RedList/ RedListGuidelines.pdf (10 July 2011).

KEELEY, S. C. \& JONES, S. B. (1979). Distribution of the pollen types in Vernonia (Vernonieae: Asteraceae). Systematic Botany 4: 195-202.

LESSING, C. F. (1829). De synanthereis herbarii regii berolinensis dissertatio prima Vernonieae. Linnaea 4: 240-356.

MATIELO-LEMOS, R. P. (2011). Características indumentares e conservação de Lessingianthus macrocephalus (Less.) H. Rob. e L. magnificus Deble, Dematteis \& Marchiori (Asteraceae: Vernonieae). In: DEBLE, L. P., DEBLE, A. S. O. \& LEÃO, A. L. S. (org.). O Bioma Pampa: contribuições científicas. Ediurcamp, Bagé, pp. 144-151.

MATZENBACHER, N. I. \& MAFIOLETI S. I. (1994a). Vernonia constricta (Compositae), nova espécies do Rio Grande do Sul, Brasil. Napaea 10: 19-20.

MATZENBACHER, N. I. \& MAFIOLETI S. I. (1994b). Estudo Taxonômico do gênero Vernonia Schreb. (Asteraceae) no Rio Grande do Sul-Brasil. Comunicações do Museu de Ciências Tecnológicas da PUCRGS. Série Botânica 1 (1): 1-133.

ROBINSON, H. (1988a). Studies in the Lepidaploa complex (Vernonieae: Asteraceae). IV. The new genus Lessingianthus. Proceedings of the Biological Society of Washington 101 (4): 929951.

ROBINSON, H. (1988b). Studies in the Lepidaploa complex (Vernonieae: Asteraceae). V. The new genus Chrysolaena. Proceeding of Biological Society of Washington 101 (4): 952-958.

SCHREBER, J. C. D. (1791). Genera Plantarum ed. 8: 381-872. 